\title{
The Effect of Promotion Through Social Media on Purchase Decision with Viral Marketing as an Intervening Variable
}

\author{
Subagyo $^{1}$, Gesty Ernestivita ${ }^{2}$, Meme Rukmini ${ }^{3}$, Arthur Daniel Limantara ${ }^{4}$ \\ \{arthur.daniel@ cahayasurya.ac.id $\left.{ }^{4}\right\}$ \\ Department of Economics, Nusantara PGRI University, Kediri, Indonesia ${ }^{1,2}$ \\ Department of Accounting, Cahaya Surya Polytechnic, Kediri, Indonesia ${ }^{3}$ \\ Department of Informatics, Cahaya Surya College of Technology, Kediri, Indonesia ${ }^{4}$
}

\begin{abstract}
This study aims to assess the importance of social media promotion in viral marketing buying choices as an interfering variable in XXX Donut and Coffee Kediri consumers. The research method used is the quantitative explanatory method. The number of pupils is unknown. While the sample was determined to be 100 respondents - the sampling technique used nonprobability techniques, namely accidental sampling. Data were collected using a questionnaire, which was then processed using path analysis by first testing the validity and reliability of the questionnaire created. The results demonstrated a significant direct influence between the promotion of purchasing decisions through social media and viral marketing in XXX Donut and Coffee in Kediri. Viral marketing can mediate the effect of promotion on purchasing decisions through social media. It has been shown that there is an indirect influence on buying decisions between promotion through social media. XXX Donut and Kediri Coffee.
\end{abstract}

Keywords: Promotion, social media, viral marketing, purchasing decisions

\section{Introduction}

The globalization and digitalization era, on the one hand, makes business opportunities more open. However, on the other hand, it is a challenge because it makes competition in the business world more competitive. Competition is due to technological developments that compete to produce quality products efficiently and changes in systems in trade, marketing, and how to transact, including how to communicate with potential consumers and customers [17]. Therefore, choosing a promotional strategy in marketing products needs to be adjusted to the times. Digital marketing, namely the use of internet facilities and other interactive technologies to create and connect identified dialogs between companies and consumers, is currently considered a marketing strategy that is effective [5]. Digital marketing can reach broad areas and even the whole world and be done 24 hours without stopping by only being connected to the internet [4]. Social media is a means of promotion proven to affect purchasing decisions [18]. Therefore, if the business can adapt to changes in people's behavior, it will open business opportunities that will be more developed, and the market share will be wider [16].

Indonesian people's behavior currently tends to like to linger in front of gadgets by opening applications, especially during the Covid 19 pandemic [15]. This condition is an opportunity for 
business people to carry out promotions through social media, which is expected to influence their product purchasing decisions. One of the businesses that take advantage of this opportunity is XXX Donut and Coffee in Kediri. XXX Donut and Coffee Kediri, the leading culinary business in Kediri, increased sales turnover and made an innovation by doing digital marketing through social media. The steps taken are to promote viral products through social media. What has to be answered is whether social media promotion can influence the buying decisions of XXX Donut and coffee users through viral marketing as an interfering variable? The objective of this survey is therefore to determine (1) the significant effect of social media promotion on consumer purchase decisions, (2) the importance of promoting viral marketing promotion via social media at XXX Donut and Coffee. (3) the significant effect of viral marketing on consumer procurement decisions and (4) knowing of the important role of social media promotion in viral marketing purchasing decisions as an interim variable in XXX Donuts and Coffee Consumers.

\section{Theoretical Review}

\subsection{Buying decision}

Kotler and Keller [10] suggest the decision to purchase the full customer is a process that from all of their experiences in learning, selecting, using, and even get rid of a product". Furthermore, Kotler and Keller [11] suggest five stages in purchasing decisions: Problems identifying, searching information, alternative assessments, buying decisions and behavior after purchase.

\subsection{Social media}

Social media is content which contains information generated by persons who use publishing technology, is extremely easy to access and aims at facilitating communication, influence and interaction with others and the public [13].

\subsection{Viral marketing}

The internet version of word-of-mouth marketing, which involves creating an email message or a marketing event which is so infectious that customers would like to pass this on to their friends, according to Kotler and Armstrong [11]. Or another understanding is the marketing of the internet version of word-of-mouth marketing, which is strongly related to creating messages or marketing methods which are so contagious that customers can and will pass them to friends. So, the term viral is used to describe the spread of messages very quickly and widely. So, viral marketing is a marketing technique using electronic or social media to achieve a marketing goal that is carried out through a chain of communication processes or reproduce themselves (see Table 1). 
Table 1. Viral marketing components

$$
\begin{gathered}
\text { Consumer } \\
\text { Buzz }
\end{gathered}
$$

Supporting Conditions

\subsection{Previous study}

Research on digital marketing strategies through social media, viral marketing and its influence on purchasing decisions has been carried out by many previous researchers. Several previous studies have found that promotion via social media has a significant influence on purchasing decisions [18],[22],[1],[6],[7],[2],[9]. Likewise, several previous studies have concluded that viral marketing has a significant impact on procurement decisions $[6],[21],[1],[19],[8]$.

\subsection{Framework of thinking}

The thinking framework is a conceptual model of how a relationship theory with several factors is defined as a problem. The relationship between promotion via social media, viral marketing and buying decisions can be described as follows, based on the formulation of the problem, as shown in Figure 1.

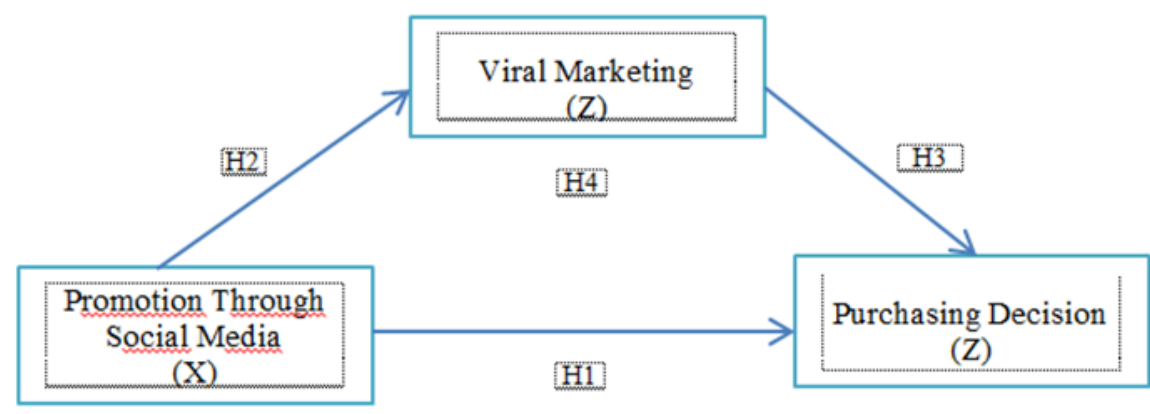

Fig. 1. Thinking framework

\section{Research Methods}

This study uses an explanatory method with a quantitative approach. The object of the research is XXX Donnut and Coffee. The exact population size is not known. The sample is determined to be 100 with the sampling technique using incidental sampling. Data were collected using a questionnaire, which was first tested using validity and reliability tests. The collected data were then analyzed using path analysis. 


\section{Research and Discussion}

\subsection{Test validity \& reliability}

This test is used to determine whether a questionnaire is valid or not. Validity tests were conducted on three main variables in this study: social media promotion, purchasing decisions and viral marketing. Judging from the results of Table 2 shows that the correlation value of each item score statement variable in the study, under the $r$ table, is $(0.165)$ which means valid. This means that all question items are able to measure the variables of purchasing decisions, promotion through social media, and viral marketing. In Table 3 the results of the Reliability test show that every variable used is said to be reliable, which means that all respondents' answers are considered consistent.

Table 2. Validity Test Results

\begin{tabular}{|l|c|c|c|c|}
\hline Variable & Statment & $\begin{array}{c}\text { Corretd Item total } \\
\text { Corelation }\end{array}$ & R table & Validity \\
\hline Purchasi & Y1 & 0,473 & 0,165 & Valid \\
\cline { 2 - 5 } Decision & Y2 & 0,762 & 0,165 & Valid \\
\cline { 2 - 5 } & Y3 & 0,614 & 0,165 & Valid \\
\cline { 2 - 5 } & Y4 & 0,528 & 0,165 & Valid \\
\cline { 2 - 5 } & Y5 & 0,550 & 0,165 & Valid \\
\cline { 2 - 5 } & Y6 & 0,630 & 0,165 & Valid \\
\cline { 2 - 5 } & Y7 & 0,395 & 0,165 & Valid \\
\cline { 2 - 5 } & Y8 & 0,519 & 0,165 & Valid \\
\cline { 2 - 5 } & Y9 & 0,691 & 0,165 & Valid \\
\cline { 2 - 5 } & Y10 & 0,546 & 0,165 & Valid \\
\hline Promotion & $\mathrm{X} 1$ & 0,580 & 0,165 & Valid \\
\cline { 2 - 5 } Through & $\mathrm{X} 2$ & 0,775 & 0,165 & Valid \\
\cline { 2 - 5 } Media & $\mathrm{X} 3$ & 0,769 & 0,165 & Valid \\
\cline { 2 - 5 } Social & $\mathrm{X} 4$ & 0,584 & 0,165 & Valid \\
\cline { 2 - 5 } & $\mathrm{X} 5$ & 0,681 & 0,165 & Valid \\
\cline { 2 - 5 } & $\mathrm{X} 6$ & 0,765 & 0,165 & Valid \\
\hline Viral & $\mathrm{Z} 1$ & 0,681 & 0,165 & Valid \\
\cline { 2 - 5 } Marketing \\
\cline { 2 - 5 } (Z) & $\mathrm{Z} 2$ & 0,809 & 0,165 & Valid \\
\cline { 2 - 5 } & $\mathrm{Z3}$ & 0,735 & 0,165 & Valid \\
\cline { 2 - 5 } & $\mathrm{Z} 4$ & 0,765 & 0,165 & Valid \\
\cline { 2 - 5 } & $\mathrm{Z} 5$ & 0,693 & 0,165 & Valid \\
\hline
\end{tabular}

Table 3. Reliability Test Results

\begin{tabular}{|l|c|c|c|}
\hline Research Variable & Cronbac's Alpha & Critical Value & Conclusion \\
\hline Puchase Dicision & 0,741 & 0,70 & Reliable \\
\hline $\begin{array}{l}\text { Promotion Trough } \\
\text { Media Social }\end{array}$ & 0,773 & 0,70 & Reliable \\
\hline Viral Marketing & 0,788 & 0,70 & Reliable \\
\hline
\end{tabular}

\subsection{Classical assumption test}

Test classic assumptions as a requirement of multiple linear regression analysis. In the classic assumption test, it is divided into multicollinearity, autocorrelation, heteroskedasticity and normality tests. In Table 4 the normality test results show that the significance values of 
each equation 1 and 2 respectively are of value> 0.05 and it is concluded that the regression model is feasible to use.

Table 4. Normality test results

\begin{tabular}{lcc}
\hline \multicolumn{1}{c}{ Unstandardized Residual } & P Value & Information \\
\hline Equation 1 & 1,036 & Data is normally distributed \\
Equation 2 & 1,187 & Data is normally distributed \\
\hline
\end{tabular}

Table 5 shows that everybody variable of equations 1 and 1 has a tolerance value $>0.20$ and a VIF value $<10$. The results of the multicollinearity test below are shown. This shows that in the regression model there is no multi-linearity problem.

Table 5. Multicollinearity test results

\begin{tabular}{|c|c|c|c|}
\hline Variable & Tolerance & VIF & Information \\
\hline Equation 1 & 1,000 & 1,000 & There is no multicollinearity \\
\hline Promotion Through & & & \\
\hline Social Media & & & \\
\hline Equation 2 & 0,899 & 1,112 & There is no multicollinearity \\
\hline Promotion Through & & & \\
\hline Social Media & & & \\
\hline Viral Marketing & 0,899 & 1,112 & There is no multicollinearity \\
\hline
\end{tabular}

While the heteroscedasticity test aims to test whether there is an unequal variance between observations in the middle of regression. The results of the heteroskeda test are shown in Table 6 below. Based on the results of the analysis in Table 6 below, each variable in equations 1 and 1 has a value ( $p$ value) $>0.1$.

Table 6. Heteroscedasticity test results

\begin{tabular}{lccc}
\hline \multicolumn{1}{c}{ Variable } & T count & Sig. & Information \\
\hline $\begin{array}{l}\text { Equation 1 } \\
\text { Promotion Through }\end{array}$ & 0,447 & 0,460 & Heteroscedasticities doesn't occur \\
$\begin{array}{l}\text { Social Media } \\
\text { Equation 2 }\end{array}$ & 1,765 & 0,681 & Heteroscedasticities doesn't occur \\
$\begin{array}{l}\text { Promotion Through } \\
\text { Social Media }\end{array}$ & & & \\
Viral Marketing & -31 & 0,975 & Heteroscedasticities doesn't occur \\
\hline
\end{tabular}

\subsection{Model test}

Model test or better known as the model feasibility test is a test that is used to measure the accuracy of the regression function. The accuracy of the model in this study is done through the measurement of the determinant coefficient values $\left(R^{2}\right)$ and F statistical test. 
Table 7. Determination coefficient test results $\left(R^{2}\right)$

\begin{tabular}{ccccc}
\hline Model & R & R Square & $\begin{array}{l}\text { Adjusted R } \\
\text { Square }\end{array}$ & $\begin{array}{l}\text { Std Error of the } \\
\text { Estimate }\end{array}$ \\
\hline 1 & 0,838 & 0,705 & 0,693 & 1,833 \\
\hline
\end{tabular}

From the results of the analysis of the coefficient of determination of data, it is known that the R Square value of 0.705 . It will be perfect $(100 \%)$ or close to perfect if there are other independent variables included in the model. This means that promotion through social media and viral marketing explains the buying decision at XXX Donnuts and Coffee Kediri 70.5\%. While 29.5 is explained by other variables outside the model.

Table 8. Statistical test results F

\begin{tabular}{lllllr}
\hline Model & \multicolumn{1}{c}{ Sum of Squares } & df & Mean Square & F & Sig \\
\hline Regression & 159.958 & 2 & 84,979 & 66,012 & 0,000 \\
Residual & 78.602 & 97 & 2,027 & & \\
Total & 308.560 & 99 & & & \\
\hline
\end{tabular}

If the value of Fcount> Ftable then $\mathrm{H} 0$ is rejected and $\mathrm{H} 1$ is accepted, then all the independent variables influence together the dependent variable or the model made is feasible. To find $\mathrm{F}$ table, first, determine the probability value and then the df value. Economic research usually uses a 5\% probability level and it is known that the first and second df values are 2 and 97, then the known Ftable value of 2.358 means that $\mathrm{H} 0$ is rejected and $\mathrm{H} 1$ is accepted. Because Fcount $>$ Ftable is 66.012>2.358. The results of the F statistical test analysis concluded that the independent variable, promotion through social media and viral marketing, simultaneously had an influence on purchasing decisions and the model made was feasible or appropriate. Table 8 shows the results of the regression path analysis in SPSS software.

\subsection{Discussions}

Table 9. Results of regression equation path analysis I

\begin{tabular}{|c|c|c|c|c|c|}
\hline Model & $\begin{array}{r}\text { Uns } \\
\text { C } \\
\end{array}$ & $\begin{array}{l}\text { andardized } \\
\text { efficients }\end{array}$ & $\begin{array}{c}\text { Standardized } \\
\text { Coefficients }\end{array}$ & $\mathbf{t}$ & Sig \\
\hline \multirow[t]{2}{*}{ (Constant) } & $\mathrm{B}$ & Std. Error & Beta & & \\
\hline & 24,804 & 4,094 & & 6,059 & 0,000 \\
\hline $\begin{array}{l}\text { Score Promotion } \\
\text { Through Social } \\
\text { Media }\end{array}$ & 0,620 & 0,155 & 0,375 & 3,999 & 0,000 \\
\hline
\end{tabular}

Table 10. Results of R square value 1

\begin{tabular}{crrrr}
\hline Model & R & R Square & $\begin{array}{c}\text { Adjusted R } \\
\text { Square }\end{array}$ & $\begin{array}{c}\text { Std Error of the } \\
\text { Estimate }\end{array}$ \\
\hline 1 & 0,373 & 0,140 & 0,132 & 3,388 \\
\hline
\end{tabular}


Table 11. Results of regression equation path analysis 2

\begin{tabular}{lrrrrr}
\hline Model & \multicolumn{2}{c}{$\begin{array}{l}\text { Unstandardized } \\
\text { Coefficients }\end{array}$} & $\begin{array}{l}\text { Standardized } \\
\text { Coefficients }\end{array}$ & T & Sig \\
\hline (Constant) & \multicolumn{1}{c}{ B } & Std. Error & \multicolumn{1}{c}{ Beta } & & \\
\cline { 2 - 6 } & 14,811 & 2,112 & & 4,135 & 0,000 \\
Score Promotion & 0,334 & 0,123 & 0,178 & 2,658 & 0,000 \\
Through Social & & & & & \\
Media & & & & & \\
Viral Marketing & 0,870 & 0,236 & 0,117 & 4,325 & 0,000 \\
\hline
\end{tabular}

Based on the analysis of equation 2 in Table 11, the regression equation is as follows:

$$
\begin{gathered}
Y=a+b 2 X 1+b 3 Z+e 2 \\
Y=14,811+0,334 X 1+0,870 Z+e 2
\end{gathered}
$$

Based on e 2 values in the first regression equation can be calculated with the formula e $2=$ $\sqrt{1-R^{2}} \mathrm{R}$ square value $2\left(R^{2} 2\right)$ means the value of $\mathrm{R}$ square in the second equation, value 2 ( $\left.R^{2} 2\right)$ ) can be seen in Table 12 below:

Table 12. Results of R Square 2 Values

\begin{tabular}{ccccrr}
\hline Model & R & R Square & \multicolumn{2}{c}{$\begin{array}{l}\text { Adjusted R } \\
\text { Square }\end{array}$} & \multicolumn{2}{l}{$\begin{array}{l}\text { Std Error of the } \\
\text { Estimate }\end{array}$} \\
\hline 1 & 0,636 & 0,405 & 0,393 & 2,833 \\
\hline
\end{tabular}

So, the value of e 2 can be calculated e $2=\sqrt{1-0,405}$ dan the result is 0.771 . The value of 2 is entered into the regression equation 2 above, and the equation becomes $\mathrm{Y}=14,881+$ $0,334 \mathrm{X} 1+0,870 \mathrm{Z}+0,771$. That means if the score is 0.334 with an error of 0.771 . And if the virtual marketing score perceived by consumers increases by one unit it will also increase the purchasing decision score by 0.870 with an error of 0.771 .

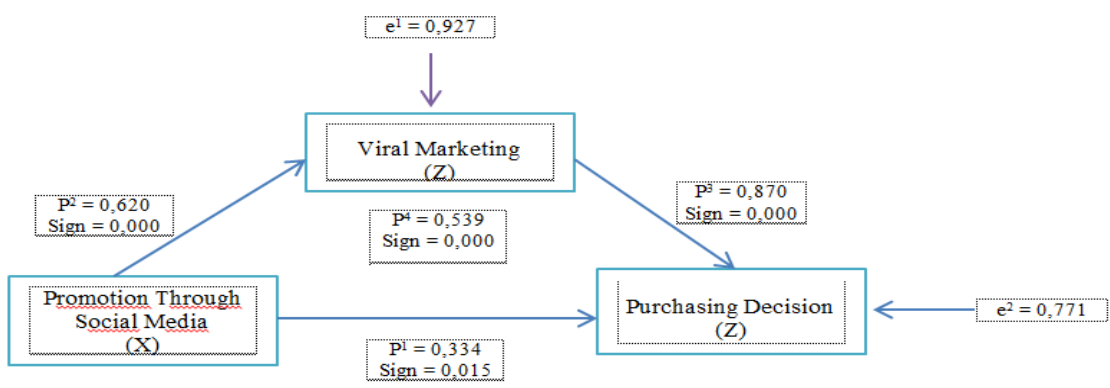

Fig. 2. Path analysis model

Based on the analysis of the path of regression equations 1 and 2, variable testing can be done partially/gradually that exerts influence between each variable. Criteria for testing variables partially have the following conditions: 
If $\mathrm{Sig}<0.1$ then $\mathrm{H} 0$ is rejected and $\mathrm{H} 1$ is accepted

If $\mathrm{Sig}>0.1$ then $\mathrm{H} 0$ is accepted and $\mathrm{H} 1$ is rejected

- the influence of promotion through social media on XXX Donnuts and Coffe's purchasing decisions. Based on the test results, the sig value is 0.015 and the beta coefficient is 0.334 . The sig value of $0.015<0.05$ means that $\mathrm{H} 1$ is accepted. This means that the promotion of purchasing decisions on XXX Donnuts and Coffee Kediri by social media will have a positive influence.

- The Effect of Social Media Promotion on Viral Marketing. Based on the test results, it shows that the sig value is 0.000 and the beta value is 0.620 . The sig value $0.000<0.05$ thus means that $\mathrm{H} 2$ is accepted, meaning that the promotion of social media and viral marketing has a significant positive influence. The influence magnitude is 0.620 .

- the effect of viral marketing on XXX Donnuts and Coffe purchasing decisions. Based on the test results, the sig value is 0.000 and the beta value is 0.870 . The sig value of $0,000<0,05$ therefore signifies acceptance of $\mathrm{H} 3$, which means that there is a significant positive effect between viral marketing on XXX Donnits and Coffee Kediri buying decisions. The influence magnitude is 0.870 .

- the effect of promotion via social media on XXX Donnuts and Coffee buying decisions with viral marketing as an intervention variable. Based on the test results, the sig value is 0.000 and the beta-coefficient value is 0.539 . Consequently, the sig value of $0,000<0,05$ means that $\mathrm{H} 4$ is accepted. This means that indirectly the promotion by social media of buying decisions at XXX Donnuts and Coffe Kediri with interfering viral marketing variables is significantly positively affected. This also shows that viral marketing can improve purchasing decision, as it can increase the beta coefficient from 0.334 before viral marketing to 0.539 after viral marketing mediation.

\section{Conclusion}

The results of research conducted on the XXX column Donnuts And Coffee Kediri can draw conclusions: - There is a significant positive effect between promotion by social media of consumer purchasing decisions made at Donnut and Coffee Kediri.

- The impact of promotion of viral marketing conducted by Donnut and Coffee by social media has been significantly positive.

- Viral marketing has a significant positive effect on consumer purchasing decisions at Donnut and Coffee Kediri.

- There is an important positive influence between social media promotion in Donnut and Coffee Kediri's buying decisions.

- Indirectly, the promotion of purchasing decisions by consumers at Donnut and Coffee Kediri through social media has a significant positive effect and viral marketing is an intermediate variable. The results also show that viral marketing is capable of promoting consumer decisions through social media. 


\section{References}

[1] Adhawiyah Y.R.,Anshori M. Isa, Fathor, 2019. Peran Pemasaran Media Sosial Dalam Menciptakan Keputusan Pembelian Melalui Kesadaran Merek, Jurnal Tirtayasa Ekonomika, Vol. 14, No 2, Oktober 2019, Hl 267 - 181.

[2] Alnsour Muhammed, Ghannam Mustafa, Al-Natour, Rawand, Alzeidat, Yousef, 2018. Social Media Effect On Purchase Intention: Jordanian Airline Industry. Journal Of Internet Banking And Commerce; Ottawa Vol. 23, Iss. 2, Page 1-16.

[3] https://search.proquest.com/docview/2122484252/c1ca91f477154423pq/7. Retrieved On September $15^{\text {th }}, 2020$.

[4] Arifin, Ali. 2003. Viral marketing: Konsep Baru Berwirausaha. Yogyakarta: Penerbit Andi Offset.

[5] Coviello, N., Milley, R. and Marcoli N,B. 2001. Understanding IT-Enabled Interactivity in Contemporary Marketing, Journal of Interactive Marketing, Vol.15 No. 4, Page 18-33.

[6] Diyatma Aris Jatmika, 2017. Pengaruh Promosi Melalui Media Sosial Instagram terhadap Keputusan Pembelian Produk Saka Bistro \& Bar, E-Proceeding of Management, Vol.4, No.1, Page 175-179

[7] Gupta, Vandana.2016. Impact Of Social Media On Purchase Decision Making Of Customers. International Journal On Global Business Management \& Research; Chennai Vol. 5, Iss. 2. Pege 73-85.

[8] Irawan Anggi, 2019. Pengaruh Viral Marketing dan Endorser terhadap Keputusan Pembelian Dengan Brand Awareness sebagai Variabel Intervening, http://repositori.uinalauddin.ac.id/15876/1/pengaruh\%20viral\%20marketing\%20dan\%20endorser\%20terhadap.pdf. Retrieved On September $15^{\text {th }}, 2020$.

[9] Khoiro Failatul, Rachma, Hufron M, 2017. Pengaruh Promosi Media Sosial terhadap Keputusan Pembelian dengan Viral Marketting Sebagai Variabel Intervening (Studi Pada Konsumen Warung Siji House And Resto Malang), Jurnal Ilmiah Riset Manajemene Prodi Manajemen Fakultas Ekonomi Unisma, Page 140-153. http://riset.unisma.ac.id/index.php/jrm/article/view/4293. Retrieved On September $18^{\text {th }}, 2018$.

[10] Kotler, Philip dan Kevin Lane Keller. 2008. Manajemen Pemasaran. Eisi 12 Jilid 2. Jakarta: Erlangga.

[11] Kotler, P., and Armstrong, G. 2004. Prinsip-prinsip Marketing. Jakarta: Salemba Empat.

[12] Muanas, Arif. 2014. Perilaku Konsumen. Yogyakarta: CV Gerbang Media Aksara.

[13] Nasrullah, Rulli. 2015. Media Sosial (perspektif komunikasi, budaya, dan sosioteknologi). Bandung : Simbiosa Rekata Media.

[14] Nggilu A., Tumbel dan .Djemly W, 2019. Pengaruh Viral Marketing, Celebrity Endorser dan Brand Awareness terhadap Keputusan Pembelian Pada Geprek Bensu Manado, Jurnal EMBA Vol.7 No.3 Juli 2019, Page $2691-2700$,

[15] Pertiwi W.K., 2020. Pandemi Bikin Orang Indonesia Makin Betah Berlama-lama Buka Aplikasi, https://tekno.kompas.com/read/2020/07/12/16050087/pandemi-bikin-orang-indonesia-makinbetah-berlama-lama-buka-aplikasi. Retrieved On September $18^{\text {th }}, 2020$.

[16] Prasetyono Agus Puji, 2017. Persaingan di Era Globalisasi dan Ekonmi Digital, https://www.ristekbrin.go.id/kolom-opini/persaingan-di-era-globalisasi-dan-ekonomi-digital/. Retrieved On Oktober $16^{\text {th }}, 2020$.

[17] Rohiman Afifatur, 2018. Era Digitalisasi Media Pemasaran Online dalam Gugurnya Pasar Ritel Konvensional , Kanal (Jurnal Ilmu Komunikasi), Vol 6. No. 2. Page 91-100. http://ojs.umsida.ac.id/index.php/kanal/article/download/1931/1449. Retrieved On Oktober $6^{\text {th }}$, 2020.

[18] Subagyo, Ernestivita G., 2017. Use of Digital Marketingg as an Effort to Increasw Sales Volume Micro, Small and Medium Enterprises Products in Kediri, Proceeding UG Economic FacultyInternational Conference 2017, Page 460 - 468.

[19] ------ 2018. Social Media Influencer: Marketing Strategy For SMES, Proceeding UG Economic Faculty-International Conference 2018. Hal. 1-11

[20] Triana N. Neni, Fachrury Muhammad Rifky, 2019. Pengaruh Promosi Melalui Media Sosial Terhadap Keputusan Pembelian Dalam Viral Marketing di CV Seragam Sekolah Bhinneka 
Karawang, Proceeding $1^{\text {st }}$ Conference on Industrial Engineering and Halal Industries (CIEHIS) Program Studi Teknik Industri, Fakultas Sains dan Teknologi, UIN Sunan Kalijaga Yogyakarta 2019, Page 108-117. http://ejournal.uin-suka.ac.id/saintek/ciehis/article/view/1551. Retrieved On Oktober $6^{\text {th }}, 2020$.

[21] Wilujeng Sri, dan Nurlela Tresna Siti, 2013. Pengaruh Viral Marketing Terhadap Keputusan Pembelian pada PT. "X”. Proceeding Seminar Nasional dan Call for Paper Sancall 2013. Page 5159. https://publikasiilmiah.ums.ac.id/bitstream/handle/11617/3838/05sri\%20wiludjeng $\% 20$ sp $\% 20 \& \% 20$ tresna\%20siti\%20nurlela.pdf;sequence $=1 . \quad$ Retrieved On September $10^{\text {th }}, 2020$.

[22] Wahk, Kee-Young; Kim, Byoungsoo, 2017. Service Business; Effects Of Social Media On Consumers' Purchase Decisions: Evidence From Taobao. Heidelberg Vol. 11, Iss. 4, (Dec 2017): 803-829. DOI:10.1007/s11628-016-0331-4. https://search.proquest.com/docview/1957691053/c1ca91f477154423pq/2. Retrieved

On September $15^{\text {th }}, 2020$.

[23] Winduarsa, Muhraha Dewa Bagus dan Kusuma A.A Gd Agung, 2015. Pengaruh Bauran Promosi Terhadap Keputusan Pembelian. E-Jurnal Manajemen, Vol 4 No, 12. Page 4160-4185. https://ojs.unud.ac.id/index.php/Manajemen/article/view/14930. Retrieved On September $10^{\text {th }}$, 2020. 